\title{
Acute Gastrointestinal Bleeding Caused by Dieulafoy Lesion of the Esophagus
}

\section{Hemorragia Digestiva Aguda Secundária a Lesão de Dieulafoy do Esófago}

\author{
Armando PEIXOTO $\rrbracket^{1}$, Regina GONÇALVES ${ }^{1}$, Guilherme MACEDO ${ }^{1}$
} Acta Med Port 2017 May;30(5):426-426 - https://doi.org/10.20344/amp.8209

Keywords: Esophagus; Gastrointestinal Hemorrhage

Palavras-chave: Esófago; Hemorragia Gastrointestinal

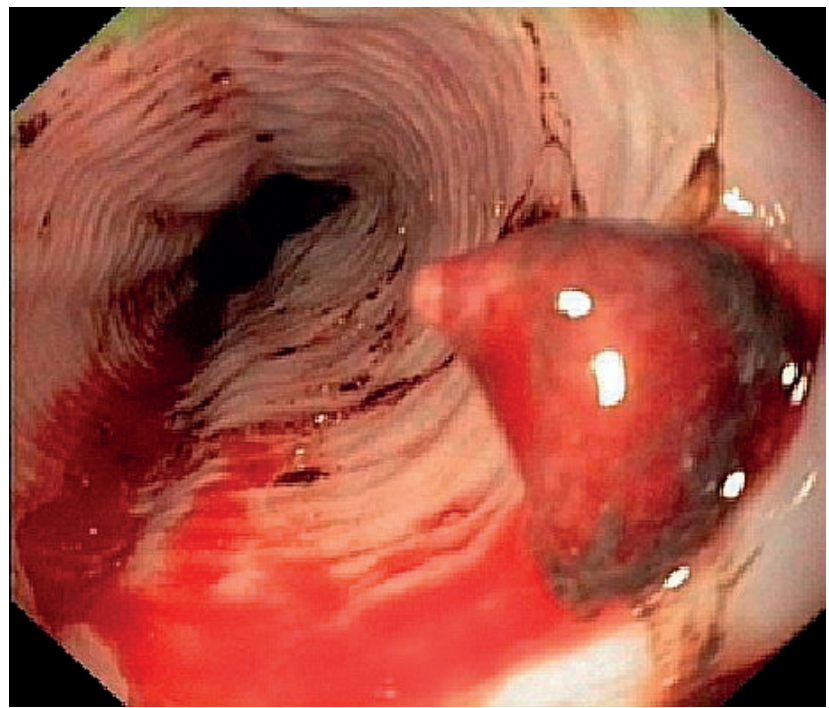

Figure 1 - Dieulafoy lesion with active bleeding in the middle esophagus

The authors report the case of a 66-year-old man admitted after fracture of the left femur, being submitted to surgery. During the recovery period the patient had an episode of large volume hematemesis with hypotension and tachycardia, with a hemoglobin decrease of $3 \mathrm{~g} / \mathrm{dL}$. After cardiovascular resuscitation, upper endoscopy was performed which revealed a bleeding vessel in the midesophagus, compatible with a Dieulafoy lesion (Fig. 1). Hemostasis was achieved with placement of a metallic clip (Fig. 2). Subsequently a contrast enhanced chest computed

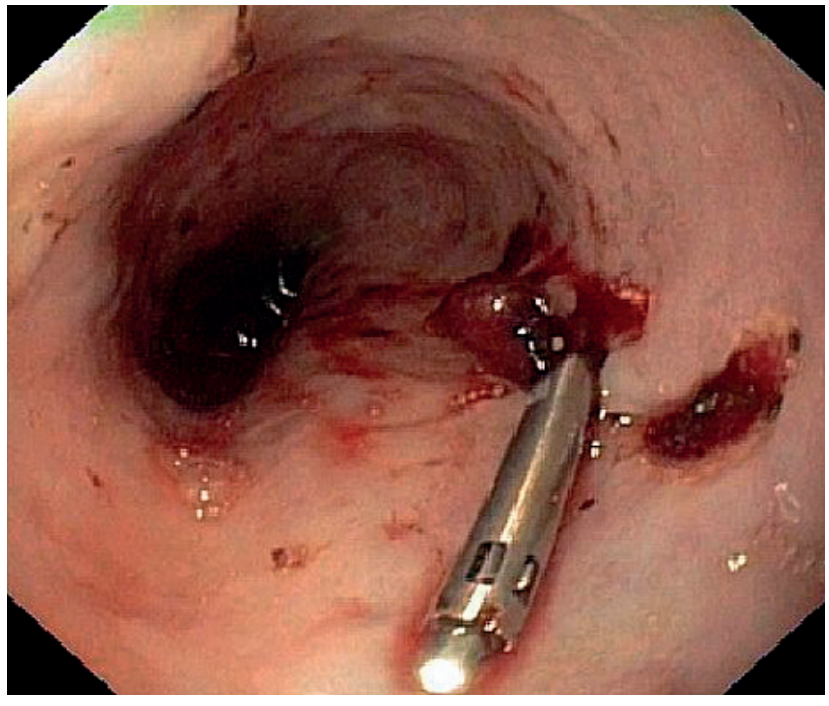

Figure 2 - Effective hemostasis after placing a metallic clip

tomography was made to exclude the other intrathoracic complications, such as aortoesophageal fistula. The patient evolved favorably without hemorrhagic recurrence.

Dieulafoy's lesion is a submucosal ectatic artery in the gastrointestinal tract ${ }^{1}$. The etiology of these lesions is unknown, and accounts for $1 \%$ to $6 \%$ of cases of acute nonvariceal upper gastrointestinal bleeding. ${ }^{2}$ The involvement of the esophagus is extremely rare. ${ }^{3}$ Endoscopic treatment is the first choice in bleeding Dieulafoy lesions. ${ }^{4}$

\section{REFERENCES}

1. Chaer RA, Helton WS. Dieulafoy's disease. J Am Coll Surg. 2003;196:290-6.

2. Tjwa ET, Holster IL, Kuipers EJ. Endoscopic management of nonvariceal, nonulcer upper gastrointestinal bleeding. Gastroenterol Clin North Am. 2014;43:707-19.

3. Scheider DM, Barthel JS, King PD, Beale GD. Dieulafoy-like lesion of the distal esophagus. Am J Gastroenterol. 1994:89:2080-1.

4. Lee YT, Walmsley RS, Leong RW, Sung JJ. Dieulafoy's lesion. Gastrointest Endosc. 2003;58:236-43.

\footnotetext{
1. Gastroenterology Department. Centro Hospitalar de São João. Faculdade de Medicina. Universidade do Porto. Porto. Portugal.

$\triangle$ Autor correspondente: Armando Peixoto armandoafp5@gmail.com

Recebido: 12 de setembro de 2016 - Aceite: 17 de fevereiro de 2017 | Copyright @ Ordem dos Médicos 2017
} 